track reforming postsocialist countries. Annals of the Association of American Geographers, 105 (1), 183-202.

Novotný, L. and Pregi, L. (2015). Changes in ethnic structure of population in the light of recent trends of migration and natural reproduction. Geographica Pannonica, 19 (4), 194-211.

Reardon, S.F. and O'Sullivan, D. (2004). Measures of spatial segregation. Sociological Methodology, 34 (1), 121-162.

Sýkora, L. (2009). New socio-spatial formations: Places of residential segregation and separation in Czechia. Tijdschrift voor Economische en Sociale Geografie, 100 (4), 417-435.

Tammaru, T., Marcińczak, S., Van Ham, M. and Musterd, S. (eds.) (2015). Socio-economic Segregation in European Capital Cities: East Meets West. UK: Taylor and Francis Inc.

Temelová, J., Novák, J., Ouředníček, M. and Puldová, P. (2011). Housing estates in the Czech Republic after socialism: Various trajectories and inner differentiation. Urban Studies, 48 (9), 18111834.

Treija, S. and Bratuškins, U. (2014). Rīgas lielmēroga dz̄̄vojamo rajonu identitāte un attīstība. In: Rozenvalds, J. and Zobena, A. (eds.) Daudzveidīgās un main̄̄gās Latvijas identitātes, Rīga: LU Akadēmiskais Apgāds, 347-361.

\title{
DEFINING THE COMMUTING REGIONS OF LATVIA
}

\section{Latvijas svārstmigrācijas reǵionu noteikšana}

\author{
Toms Skadiňs \\ University of Latvia, Faculty of Geography and Earth Sciences \\ toms.skadins@lu.Iv
}

\begin{abstract}
In this research paper the geography of travel to work is analysed based on origin-destination commuting flows between municipalities. The aim of this study is to define work-related commuting regions of Latvia using the most recent data derived from the 2011 Population Census. The analysis demonstrates potential insights to be gained in defining regional patterns in the structure of work-related commuting flows using census data. The findings identify 17 commuting regions in Latvia and highlight the importance of Rìga in the context of the Latvian labour market. Two types of commuting regions were identified - mono-centric regions attracting large numbers of commuters in the main employment centre and poly-centric regions with more diversified travel-to-work flows.
\end{abstract}

Keywords: travel-to-work patterns, commuting behaviour, regions, census.

\section{Introduction}

In the last few decades, the processes of mobility (population movement) have had a tendency to become more diverse and more voluminous. Travel-to-work flows between municipalities represent a significant part of human mobility. Studies on the peculiarities of work-related commuting in post-socialist countries have mostly focused on the largest cities and their urban regions or agglomerations (Ahas et al. 2010; Novak and Sykora 2007; Novotny 2016). Country-wide or regional commuting patterns have been studied considerably less frequently (e.g. Klapka et al. 2013; Kraft et al. 2014; Marcinczak and Bartosiewicz 2018). The Statistical Bureau of Estonia has defined labour migration regions based on 2011 Census data (Statistics Estonia 2014). ESPON functional urban regions research has paid attention to all regional types 
(ESPON 2005). However, researchers, including Ludek Sykora and Ondrej Mulicek (2009), argue that their approach ends up providing imprecise information about agglomerations which is contrary to the results of all previous research.

In Latvia, the research has also largely focused in past on various facets of commuters in the Rīga agglomeration (Krišjāne and Bērziņš 2009; Krišjāne et al. 2012). The borders of the Riga agglomeration have been re-defined four times (first occasion in 1996) since the fall of socialism in 1991 (Bauls et al. 1999; RDPAD 2004; RDPAD 2012; RDPAD 2017). One notable exception is the research on "Latvian Population Mobility in the Transitional Period" (Bauls and Krišjāne 2000), where labour commuting flows to the largest cities were analysed for the years 1991 and 1999. However, nearly two decades have passed since these studies, and there is still a lack of sufficient knowledge concerning commuting patterns outside the Riga agglomeration. Other largest cities and non-metropolitan regions house approximately $45 \%$ of the Latvian population and that is an important part of the national labour market (RDPAD 2017).

The aim of this study is to define the work-related commuting regions of Latvia using the most recent data derived from the 2011 Population Census.

\section{Data and Methods}

The commuting of employed persons between the administrative territories (municipalities) is the dataset that was used for this paper. Data was generated by processing the information on residence and workplace addresses (their so-called mismatch) from the 2011 Population Census. Only municipalities between which commuting flows are at least 10 people were included in this dataset.

In-bound and out-bound commuting flows among municipalities, as well as turnover, was analysed not just to define the commuting regions, but also to characterize the general patterns. Data on total population was used to explain some of the results, namely the differences between regions. The following steps were utilised to define the commuting regions of Latvia:

- First, the main employment centres were identified (based on in-bound commuting flows);

- Next, it was determined whether (and how) municipalities are connected to the main employment centres;

- Based on the connections, it was identified whether these centres have a significant number of (voluminous) connections, so that a region can be defined;

- Those municipalities which did not have a pronounced connection with any centre were further analysed to determine their connections and, conversely, whether a municipality is the main centre, one of the centres or simply a part of a region. For this purpose, both out-commuters and in-commuters were analysed. Since most municipalities outside of the Rīga commuting hinterland had a small number of (significant) connections with other 
municipalities, only the most voluminous were considered. No commuter thresholds were defined for creation of regions, due to significant differences between the various municipalities;

- Two types of regions were identified: mono-centric and poly-centric. The former had either a main employment centre or municipalities that encompass the largest regional cities as their core. Whilst poly-centric regions had more diversified travel-to-work flows among several municipalities;

- In some isolated cases a municipality was included into the particular region despite not having a significant connection with the employment centre. The reason for inclusion was that it had a significant link with other municipalities belonging to that region.

The commuting hinterland of the capital city was defined differently. For a municipality to be a part of Pierīga region, the number commuters to and from Rīga had to be above the average (national level), which is heavily impacted by numbers in the municipalities near Rīga, meaning that members of this region have the highest numbers in country; 1007 and 191 respectively and with a strong connection to other municipalities of the hinterland. For municipalities to be included in the Lielrīga region, such characteristics had to be met - a below average number of commuters in at least one of the two instances (to or from Rīga) and/or a prevalent connection with other Lielrīga region municipalities. The reason for this type of criteria is that for most municipalities the number one out-bound connection is with Rīga. Both regions were classified as poly-centric, since commuting within these regions was more pronounced than for any other region (especially for Pierīga).

Region names were derived from the Statistical regions of Latvia - a level of territorial aggregation, which (to an extent) shows the four historical / cultural regions of Latvia. There are some exceptions, meaning there are municipalities that belong to different regions.

\section{Results}

Based on the number of commuters between municipalities, derived from the 2011 Population Census, a total of 17 labour commuting regions were identified, with 11 of them being mono-centric. They are shown in Table 1.

The capital city of Riga, due to its being the main employment centre of Latvia, is not a part of any region, rather it is a region by itself. In every municipality (119) there are at least 10 people who work in Rīga, whereas at least 10 people from Rìga travel to work in 83 municipalities. Rìga is the main destination of commuters from 81 municipalities. A total of 119970 people commute to Rīga, while 15825 people commute from the capital. This region is the only one where in-bound commuters outnumber their counterparts. 
Table 1. Commuting regions of Latvia by type (author's calculations, based on CSB 2018)

\begin{tabular}{|c|c|c|c|}
\hline \multicolumn{2}{|c|}{ Mono-centric regions } & \multicolumn{2}{|c|}{ Poly-centric regions } \\
\hline $\begin{array}{c}\text { Region / city - } \\
\text { employment centre }\end{array}$ & $\begin{array}{l}\text { Total number of } \\
\text { commuters (in-bound } \\
\text { and out-bound) }\end{array}$ & Region & $\begin{array}{l}\text { Total number of } \\
\text { commuters (in-bound } \\
\text { and out-bound) }\end{array}$ \\
\hline Kurzeme - Liepāja & 15379 & Northern Kurzeme; & 12987 \\
\hline Latgale - Balvi & 1727 & $\begin{array}{l}\text { Southern and Central } \\
\text { Kurzeme }\end{array}$ & 7391 \\
\hline Latgale - Daugavpils & 17094 & Lielrīga & 56298 \\
\hline Latgale - Ludza & 3330 & Pierīga & 79665 \\
\hline Latgale - Preiḷi & 3399 & $\begin{array}{l}\text { East - North East } \\
\text { Vidzeme }\end{array}$ & 5419 \\
\hline Latgale - Rēzekne & 11283 & Northern Zemgale & 6733 \\
\hline Rīga & 135795 & Sum & 168493 \\
\hline Vidzeme - Cēsis & 10143 & & \\
\hline Vidzeme - Valmiera & 16003 & & \\
\hline Zemgale - Jēkabpils & 8591 & & \\
\hline Zemgale - Jelgava & 25695 & & \\
\hline Sum & 248439 & & \\
\hline
\end{tabular}

Most of the municipalities belong to Lielrīga region (19). These territories are not as connected to Rīga as the ones from Pierīga region. However, this connection is significant enough. Another characteristic separating these two groups is that commuting between neighbouring municipalities is less prevalent (less varied). Similarly to other regions, municipalities of this region have a higher number of outbound commuters. However, the two regions stand out in this aspect due to significantly higher numbers. The total number of out-bound commuters (43469) is three times as many as in-bound commuters (12829). The Lielrīga region is the only non-continuous region, since it has two parts, as seen in Figure 1.

Nine territories belong to the Pierīga region. These territories are closely linked to Rìga, since it is the main destination for labour commuters and one of the main sources of in-bound commuters. These municipalities are closely linked to the capital due to the common labour market and also due to proximity, which is an important pre-requisite of commuting (Boyle et al. 1998; Sultana and Weber 2007). Commuting between these municipalities is common but not as common as to Rìga. Pierīga has an even higher number of out-bound commuters - 54706, more than twice as many as inbound ones (24959).

The Liepāja region consists of nine municipalities located in westernsouthwestern Kurzeme. The City of Liepāja has the sixth largest number of in-bound commuters (right behind Olaine municipality). This region has 6608 in-bound commuters, with 5035 of them travelling to Liepāja, and 8771 out-bound commuters. 


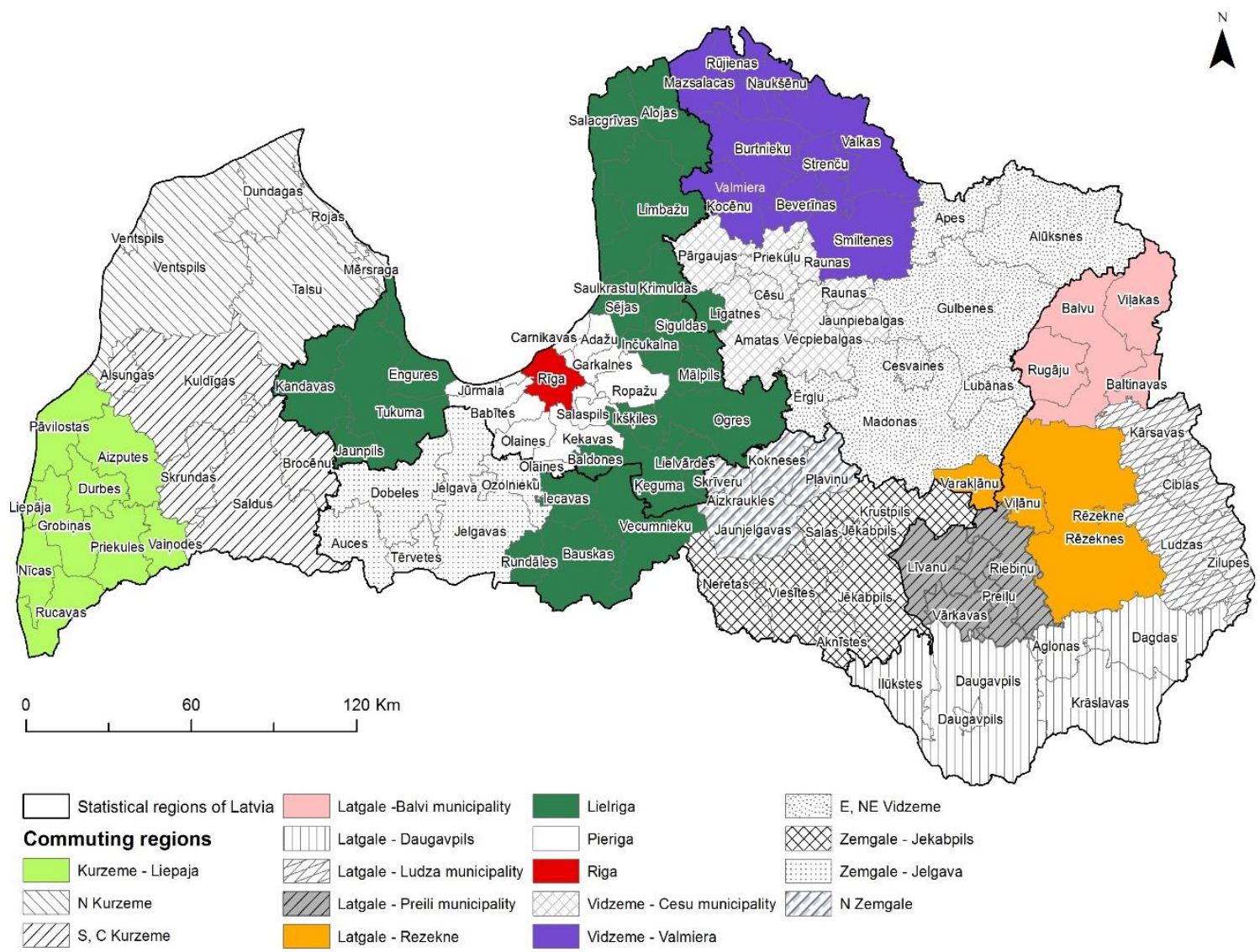

Figure 1. Commuting regions of Latvia (author's figure based on Central Statistical Bureau of Latvia data)

There are two other Kurzeme regions. Unlike the Liepāja region these regions are not mono-centric. The northern region has two centres - Ventspils and Talsi municipality. The former has less connections yet attracts more commuters, whereas the latter is more connected within the region. 4588 individuals commute in to the municipalities of this region, whereas 8399 commute out from them. The other region, which covers the rest of Kurzeme, also has two centres (the municipalities of Kuldiga and Saldus) but has a smaller number of commuters - 2368 to and 5023 from.

The Daugavpils region stretches through the southern part of Latgale, encompassing six municipalities. Its centre has the fourth largest number of in-bound commuters (right behind Mārupe municipality) - 5575. Despite the city of Daugavpils being an important regional centre, this region is also predominantly a commuter sender region, with 6521 in-bound commuters and 10573 out-bound commuters.

The Latgale - Balvi municipality region, along with three other Latgale regions of Rēzekne, Ludza municipality and Preili municipality, is tied to the smallest number of municipalities (four) that make up a region. In terms of numbers it has the smallest number of both in-bound and out-bound commuters (525 and 1675). Also, it has the smallest difference between these commuter groups (-1150) behind Rìga. Another unique characteristic is that the centre of this region is the main source of in-bound commuters for other municipalities of the region. Two other regions of Latgale also have a small number of commuters - 1087 and 2243 for the Ludza region; 1109 and 
2290 for the Preili region. Rēzekne has the smallest number of connections, with three, because Varaklāṇi municipality is more connected to neighbouring Viḷāni. Nevertheless, commuter numbers are much higher than for all other Latgale regions, except Daugavpils. 4874 people commute to the municipalities of this region, whereas there are a total of 6409 in-bound commuters.

The third largest region (10 municipalities), is Vidzeme - Valmiera region. Most municipalities in this group have a strong link with Valmiera, but commuting within the region is quite pronounced, which is why, despite having a lesser connection to the centre, Naukšēni municipality was included in this region. The total number of inbound commuters (6913) is higher than, for instance, that of the Daugavpils and Liepāja regions. The number of out-bound commuters is 9090.

Another mono-centric region in Vidzeme is the Cêsis municipality region. It encompasses a total of seven municipalities. Commuting is not as pronounced as for the Valmiera region. The municipalities of this region have 4136 in-bound commuters and 6007 out-bound.

Seven municipalities make up the Eastern, Northeastern Vidzeme region. Madona municipality is the main centre, while Alūksne is also a significant sender and receiver of commuters. 5043 people commute from the municipalities of this region but there are only 1690 in-bound commuters.

The Zemgale - Jelgava region, consisting of seven municipalities, is an interesting case. The city of Jelgava does have a major connection with Rìga (6363 commuters to Rīga and 523 from Rīga; both above average values); however it is also an important regional centre. As a matter of fact, Jelgava has the second largest number of in-bound commuters (6309). For this reason, the city is the centre of the Zemgale - Jelgava region and not a part of the Pierīga or Lielrīga region. In total, the municipalities of this region have 8349 in-bound commuters (mostly to Jelgava) and 17346 out-bound commuters, making it the most active region after Rīga, Pierīga and Lielrīga. The Auce and Tērvete municipalities are included in this region, while being more closely linked to Dobele municipality, which in turn has a link with Jelgava.

Northern Zemgale is a poly-centric region (centres - Aizkraukle and Jaunjelgava municipalities), whereas Zemgale - Jēkabpils, as the name suggests, is mono-centric. That is not the only difference - The northern region has a much smaller number of inbound commuters (1192 compared to 3282). The difference between out-bound commuters is not as significant, with the Jēkabpils region having a total of 5309 and Northern having 4227 commuters.

\section{Conclusions}

The results of this study clearly highlight the importance of Rìga in the national labour market in terms or work-related commuting. The number of people travelling to work in the capital city far exceeds the number of commuters travelling to the other largest employment centres. 
The Pierīga and Lielrīga regions reflect the commuting range of Rīga, which is especially evident by the structure of out-bound flows from Rìga. These flows are significantly higher in areas near the capital, due to development and expansion of businesses (also known as commercial suburbanisation) in recent years. In-bound flows play a lesser role, since for most municipalities the number one out-bound connection is with Riga. Nevertheless, the flows tend to be higher in the vicinity of Rìga. This could be explained by the large numbers of people who have moved from Rìga to the suburbs, while retaining their jobs in the capital (residential suburbanisation).

Results also indicate that the other largest employment centres - cities, except Jūrmala and Ventspils, form mono-centric regions with numerous significant connections. Jūrmala is an integral part of the Pierīga region, where out-bound commuting is more prominent. Meanwhile, the city of Ventspils only has a major connection with Ventspils municipality, which could be explained by the fact that other municipalities of Northern Kurzeme are located far from this city.

In general, mono-centric regions attract large numbers of commuters while polycentric regions have more diversified travel-to-work flows with several employment centres.

This study paves the way for future research. Available data allows for in-depth analysis to be conducted. This dataset allows to calculate numerous variables and to explore, as well as analyse, regional differences.

\section{Acknowledgement}

This study was supported by National Research Program Project N ${ }^{\circ}$.VPP-IZM2018/1-0015.

\section{Kopsavilkums}

Šajā pētījumā analizēta ceḷa uz darbu geogrāfija, ņemot vērā svārstmigrantu plūsmu starp pašvaldībām. Šī pētijuma mērkịis ir noteikt svārstmigrācijas reǵionus, izmantojot jaunākos datus, kas iegūti 2011. gada Tautas skaitīšanā. Analīze parāda potenciālos ieskatus, kurus var iegūt, definējot ar darbu saistītu pārvietošanās plūsmu struktūru reǵionālos modeḷus, izmantojot Tautas skaitišanas datus. Rezultāti parāda, ka Latvijā ir 17 svārstmigrācijas reǵioni, un uzsver Rīgas nozīmi valsts darba tirgū. Tika identificēti divi reǵionu veidi - monocentriski, kas piesaista lielu skaitu svārstmigrantu galvenajā nodarbinātības centrā, un policentriski ar daudzveidīgākām pārvietošanās plūsmām.

\section{References}

Ahas, R., Aasa, A., Slim, S. and Tiru, M. (2010). Daily rhythms of suburban commuters' movements in the Tallinn metropolitan area: case study with mobile positioning data. Transportation Research. 18C, 45-54.

Bauls, A. and Krišjāne, Z. (2000). Latvian population mobility in the transition period. Folia Geographica. 10, 24-35.

Bauls, A., Melbārde, Z. and Šķinķis, P. (1999). Rīgas aglomerācijas robežu noteikšana nepilnīgas informācijas apstākḷos. G̣eogrāfiski Raksti. Folia Geographica. 8, 86-94.

Boyle, P., Halfacree, K. and Robinson, V. (1998). Exploring Contemporary Migration. Essex: Longman. 
CSB (2018). LR Centrālās statistikas pārvaldes datu bāze - Nodarbināto iedzīvotāju svārstmigrācija starp administratīvajām teritorijām. https://data.gov.lv/dati/dataset/svarstmigracija (26.12.2018)

CSB (2018). LR Centrālās statistikas pārvalde - CSP datu bāzes. https://www.csb.gov.lv/lv/statistika/db (26.12.2018)

ESPON. (2005). Potentials for polycentric development in Europe. ESPON 1.1.1. project report.

Kraft, S., Halas, M. and Vancura, M. (2014). The delimitation of urban hinterlands based on transport flows: A case study of regional capitals in the Czech Republic. Moravian Geographical Reports. 22 (1), 24-32.

Klapka, P., Halas, M., Tonev, P. and Bednar, M. (2013). Functional regions of the Czech Republic: comparison of simpler and more advanced methods of regional taxonomy. Acta Universitatis Palackianae Olomucensis-Geographica. 44 (1), 45-57.

Krišjāne, Z. and Bērziņš, M. (2009). Commuting and the deconcentration of the post-socialist urban population: the case of the Rīga agglomeration. Folia Geographica. 14, 56-74.

Krišjāne, Z., Bērziņš, M., Ivlevs A. and Bauls, A. (2012). Who are the typical commuters in the postsocialist metropolis? The case of Riga, Latvia. Cities. 29 (5), 334-340.

Marcinczak, S. and Bartosiewicz, B. (2018). Commuting patterns and urban form: Evidence from Poland. Journal of Transport Geography. 70, 31-39.

Novak, J. and Sykora, L. (2007). A city in motion: Time-space activity and mobility patterns of suburban inhabitants and the structuration of the spatial organization of Prague metropolitan area. Geografiska Annaler. 89B (2), 147-167.

Novotny, L. (2016). Urban development and migration processes in the urban region of Bratislava from the post-socialist transformation until the global economic crisis. Urban Geography. 37 (7), 10091029.

Rīgas Domes Pilsētas attīstības departaments (2004). Rīgas aglomerācijas robežu precizēšana. SIA CTB.

Rīgas Domes Pilsētas attīstības departaments, LU Cilvēka ǵeogrāfijas katedra. (2012). Rīgas aglomerācijas robežu precizēšana http://www.sus.lv/sites/default/files/media/faili/2012_rigas_aglomeracijas_robezu_precizesana.pdf (26.12.2018)

Rīgas domes Pilsētas attīstības departaments, LU Cilvēka ǵeogrāfijas katedra. (2017). Rīgas aglomerācijas robežu precizēšana http://www.sus.lv/sites/default/files/rigas_aglomeracija_2017.pdf (26.12.2018)

Statistics Estonia. (2014). Eesti piirkondlik areng. Regional Development in Estonia https://www.stat.ee/publication-2014_regional-development-in-estonia-2014 (26.01.2019)

Sultana, S. and Weber, J. (2007). Journey-to-work patterns in the age of sprawl: Evidence from two midsize southern metropolitan areas. The Professional Geographer. 59 (2), 193-208.

Sykora, L. and Mulicek, O. (2009). The micro-regional nature of functional urban areas (FUAs): lessons from the analysis of Czech urban and regional system. Urban Research and Practice. 2 (3), $287-$ 307. 